\title{
IDENTIFIKASI CERITA ANAK BERBASIS BUDAYA LOKAL UNTUK MEMBUDAYAKAN LITERASI DI SD
}

\author{
Isnaeni Wahab \\ $\mathrm{I}^{\text {st }}$ Universitas Muslim Maros \\ isnaeni@umma.ac.id \\ Nurhadifah Amaliyah \\ $2^{\text {nd }}$ Universitas Megarezky \\ nurhadifah.amaliyah05@gmail.com
}

\begin{abstract}
Abstrak
Budaya lokal adalah jati diri sebuah daerah yang mana di zaman sekarang ini keistimewaannya semakin terkikis oleh budaya asing. Hal ini terjadi karena mudahnya budaya asing masuk dan berbaur dengan budaya lokal yang secara langsung dapat mempengaruhi struktur budaya bangsa. Begitu juga dengan cerita rakyat yang seakanakan terlupakan. Cerita rakyat merupakan salah satu warisan kebudayaan nasional yang menjadi kehormatan bangsa dengan budaya yang beraneka ragam yang harus diperkenalkan kepada siswa sejak sekolah dasar. Penelitian ini bertujuan untuk mengidentifikasi jenis cerita anak berbasis budaya lokal dan mengimplementasikan budaya literasi di SD Kartika XX-I Kota Makassar. Pendekatan yang digunakan dalam penelitian ini adalah deskriptif kualitatif dengan metode survey sedangkan tekhik pengumpulan data yang digunakan adalah observasi, dokumentasi, wawancara dan kuesioner. Berdasarkan data yang diperoleh, peneliti mengidentifikasi dua belas judul cerita anak yang kemudian dilakukan literasi kepada siswa SD Kartika XX-I Makassar. Penerapan budaya literasi yang dilakukan di SD Kartika XX-1 Makassar dengan 1) membagikan buku cerita kepada siswa 2) membaca sekitar 15-20 menit, 3) siswa mengidentifikasi nilai moral yang terdapat dalam cerita tersebut, 4) melakukan penguatan nilai-nilai moral cerita anak dan penerapan budaya lokal yang sesuai dengan nilai kebangsaan.
\end{abstract}

Kata kunci: cerita anak, budaya lokal, dan budaya literasi

\section{PENDAHULUAN}

Pendidikan adalah salah satu sektor penting agar sebuah negara dapat dikatakan maju dan berkembang. Tingginya pendidikan yang dimiliki oleh sumber daya manusia dalam suatu negara tentu akan menjamin pengelolaan yang baik pula terhadap sumber daya yang ada dalam negara. Oleh sebab itu, Indonesia menempatkan pendidikan sebagai sesuatu yang penting dan utama. Budaya literasi dini penting untuk dikembangkan guna membentuk perilaku dan kecakapan hidup yang diharapkan di masyarakat. Secara sederhana, literasi diartikan sebagai sebuah kemampuan membaca dan menulis. Sulhan (2006: 91) menyatakan bahwa "kemampuan literasi (mendengar, berbicara, membaca, dan menulis) merupakan kemampuan dasar yang perlu dikuasai siswa dalam meraih cita-citanya". Salah satu hal yang paling ditekankan dalam budaya literasi adalah peningkatkan kemampuan membaca siswa.

Di era globalisasi seperti sekarang ini, budaya lokal yang harusnya menjadi keistimewaan dan jati diri bangsa semakin terkikis oleh budaya asing. Hal ini terjadi karena mudahnya budaya asing masuk dan berbaur dengan budaya lokal yang secara langsung dapat mempengaruhi struktur budaya bangsa. Begitu juga dengan cerita rakyat 
yang seakan-akan terlupakan. Cerita rakyat merupakan salah satu warisan kebudayaan nasional yang menjadi kehormatan bangsa dengan budaya yang beraneka ragam yang harus diperkenalkan kepada siswa sejak usia dini. Alasan mendasar pemilihan cerita anak sebagai pendamping buku pelajaran tersebut, berakar pada siswa SD belum mampu mengetahui cerita anak berbasis budaya lokal. Kebanyakan yang ada dalam buku pelajaran, cerita anak yang ditampilkan berasal dari daerah lain, sedangkan cerita anak yang berasal dari budaya lokal, dalam hal ini budaya Bugis Makassar masih sangat kurang, siswa kebanyakan belum mengetahui budaya lokal sendiri karena sangat minimnya pengenalan cerita anak berbasis budaya lokal tersebut. Menurut Syarif (2016, h. 14) Integrasi nilai-nilai budaya dalam proses pembelajaran memiliki arti penting dalam pembentukan kepribadian peserta didik. Sedangkan sekolah dasar adalah masa dimana anak-anak berada di usia emas (golden age) sehingga sangat penting untuk menanamkan budaya membaca dan nilai nilai budi pekerti luhur, menurut Suyadi (2010, h. 06) menyatakan bahwa periode emas berlangsung pada saat anak dalam kandungan hingga usia dini, yaitu 0-6 tahun.

Suku Bugis merupakan suku bangsa Indonesia yang mendiami sebagian besar wilayah di Sulawesi Selatan. Suku Bugis dikenal sebagai suku perantau yang banyak meninggalkan wilayah aslinya untuk menyebar ke daerah-daerah lain. Salah satu nilai kebudayaan suku Bugis yang paling tua adalah adat dalam mempertahankan harga diri. Selain itu menurut Buchori \& Fakhri (2018, hal.4) Suku Bugis-Makassar dikenal memiliki nilai-nilai budaya yang terhormat, bermartabat dan damai. Nilai-nilai budaya yang luhur ini menjadi nilai yang tertanam dalam diri dan diaplikasikan dalam bentuk perilaku oleh setiap masyarakat Bugis-Makassar. Nilai-nilai ini menjadi kearifan lokal yang dijunjung tinggi warisan dari nenek moyang yang menandakan kecirikhasan suatu budaya.

Penelitian ini dilakukan untuk mengidentifikasi cerita anak berbasis budaya bugis Makassar yang ada di sekolah dasar, karena SD adalah bagian integral dari upaya pendidikan yang berbasis pengenalan budaya yang ada di masyarakat dalam mencerdaskan kehidupan bangsa dan penanaman nilai-nilai budaya agar tidak punah. Keberadaan cerita-cerita anak yang berbasis budaya lokal di Sekolah Dasar tampaknya semakin menjadi suatu keharusan untuk menjawab berbagai tantangan zaman dan perubahan kebutuhan pendidikan. Budaya literasi dapat dilakukan dengan salah satu cara yaitu membaca cerita anak berbasis budaya lokal yang tentu saja memiliki nilai luhur dari setiap ceritanya. Menurut Fatimah (2017, hal. 268) bahwa Cerita rakyat adalah sebuah warisan budaya nasional yang mempunyai nilai-nilai luhur yang dapat dikembangkan dan dimanfaatkan untuk kehidupan masa kini hingga masa yang akan datang. Oleh karena itu, Tujuan penelitian ini adalah untuk mengidentifikasi cerita anak berbasis budaya lokal khususnya budaya bugis Makassar untuk membudayakan literasi di SD Kartika XX-1 Kota Makassar.

\section{KAJIAN PUSTAKA}

Cerita anak adalah karangan yang menuturkan perbuatan, pengalaman, kejadian yang ditujukan untuk anak yang muatan ceritanya sederhana, kompleks dan komunikatif serta mengandung nilai moral bagi anak. Menurut Kamus Besar Bahasa Indonesia (KBBI) cerita anak adalah 1) tuturan yang membentangkan bagaimana terjadinya suatu hal (peristiwa, kejadian, dsb) 2) karangan yang menuturkan perbuatan, pengalaman, 
atau penderitaan orang; kejadian dsb (baik yang sungguh-sungguh terjadi maupun yang hanya rekaan belaka); 3) lakon yang diwujudkan dalam gambar hidup (sandiwara, wayan, dll). Sarumpaet (2003: 108) berpendapat bahwa cerita yang ditulis, berbicara mengenai kehidupan anak dan sekeliling hanya dapat dinikmati oleh anak dengan bantuan dan pengarahan orang dewasa.

Jenis cerita anak dapat dikelompokan menjadi cerita jenaka, dongeng, fabel, legenda, dan mite atau mitos (Rosdiana, dkk., 2013, h. 6.8). Jenis cerita yang cocok untuk anak usia SD diantaranya: (1) Dongeng adalah cerita yang didasari atas anganangan atau hayalan. Dongeng merupakan suatu cerita yang hidup dikalangan rakyat yang disajikan dengan cara bertutur lisan. (2) Cerita rakyat merupakan cerita yang alurnya mirip dengan legenda, yang mengungkap penyelesaian masalah secara baik dan adil. (3) Puisi merupakan nyanyian tanpa notasi. Puisi merupakan bentuk karya satra yang paling imajinatif dan mendalam mengenai alam sekitar, cinta, kasih sayang, perjuangan, dll. (4) Fabel adalah cerita yang menampilkan hewan-hewan sebagai tokohtokohnya. Fabel adalah cerita yang digunakan untuk pendidikan moral. (5) Legenda adalah cerita yang berasal dari zaman dahulu. Cerita legenda bertalian dengan sejarah yang sesuai dengan kenyataan yang ada pada alam. (6) Mite Atau Mitos merupakan cerita yang berkaitan dengan kepercayaan kuno, menyangkut kehidupan dewa-dewa atau kehidupan makhluk halus.

Beers (dikutip di Teguh, 2017, h. 23-24) mengatakan bahwa Gerakan budaya literasi sekolah hendaknya menekankan prinsip-prinsip sebagai berikut: (1) Perkembangan literasi berjalan sesuai tahap perkembangan anak. (2) Bersifat berimbang yang menerapkan program literasi karena tiap siswa memiliki kebutuhan yang berbeda. Oleh karena itu, strategi membaca dan jenis teks yang dibaca perlu divariasikan dan disesuaikan dengan jenjang pendidikan. (3) Terintegrasi dengan kurikulum dan pembelajaran literasi di sekolah adalah tanggung jawab semua guru di semua mata pelajaran, sebab pembelajaran apapun membutuhkan bahasa, terutama membaca dan menulis. (4) Kegiatan membaca dan menulis dilakukan kapan pun. (5) Kegiatan literasi mengembangkan budaya lisan kelas berbasis literasi yang kuat. (6) Mampu menjadi garis depan dalam pengembangan budaya literasi untuk menciptakan budaya literasi yang positif di sekolah.

Gerakan literasi di sekolah merupakan suatu usaha atau kegiatan yang bersifat partisipatif dengan melibatkan warga sekolah (peserta didik, guru, kepala sekolah, tenaga kependidikan, pengawas sekolah, komite sekolah, orang tua atau wali murid peserta didik), akademisi, penerbit, media masa, masyarakat, dan pemangku kepentingan di bawah koordinasi Direktorat Jenderal Pendidikan Dasar Dan Menegah Kementerian Pendidikan Dan Kebudayaan (Yuniati, dkk., 2017, h. 368).

Kemajemukan budaya lokal di Indonesia tercermin dari keragaman budaya dan adat istiadat dalam masyarakat. Setiap suku bangsa tersebut tumbuh dan berkembang sesuai dengan alam lingkungannya. Budaya lokal mencerminkan kearifan lokal budaya setempat. Adapun Definisi kearifan lokal adalah identitas atau kepribadian budaya sebuah bangsa yang menyebabkan bangsa tersebut mampu menyerap, bahkan mengolah kebudayaan yang berasal dari luar/bangsa lain menjadi watak dan kemampuan sendiri, Wibowo (2015: 17). Identitas dan kepribadian yang menyesuaikan dengan pandangan hidup masyarakat sekitar agar tidak terjadi pergesaran nilai-nilai. Pendapat lain dari mengatakan bahwa merupakan suatu pandangan hidup dan ilmu pengetahuan serta berbagai strategi kehidupan yang berwujud aktivitas yang dilakukan oleh masyarakat lokal dalam menjawab berbagai masalah dalam pemenuhan 
kebutuhan mereka. Dalam bahasa asing sering juga dikonsepsikan sebagai kebijakan setempat local wisdom atau pengetahuan setempat local knowledge atau kecerdasan setempat local genious, Fajarini (2014:123).

\section{METODE}

\section{Desain Penelitian}

Penelitian ini merupakan penelitian kualitatif dengan pendekatan deskriptif. Data-data deskripsi ditabulasi dan disketsa agar memberi temuan tentang identifikasi cerita anak berbasis budaya lokal. Metode yang digunakan dalam penelitian ini adalah metode survey.

Subjek penelitian terdiri dari 3 orang ahli budaya yang terdiri dari masyarakat, guru SD dan pustakawan serta sampel penelitian adalah siswa kelas IV, V dan VI SD Kartika XX-1 Kota Makassar yang berjumlah 45 dengan menggunakan teknik random sampling.

Tabel 1. Sampel Siswa SD Kartika XX-1 Kota makassar

\begin{tabular}{ccc}
\hline No & Kelas & Jumlah \\
\hline 1 & IV & 15 \\
2 & V & 15 \\
3 & VI & 15 \\
& Jumlah & $\mathbf{4 5}$ \\
\hline
\end{tabular}

Instrumen dalam penelitian yang akan digunakan adalah pedoman wawancara, kuesioner dan dokumentasi. Penelitian ini dimulai dengan mengidentifikasi cerita anak berbasis budaya lokal yang ada di masyarakat dengan melakukan kunjungan ke perpustakaan Kota Makassar. Hal tersebut dilakukan untuk memperoleh data tentang referensi buku cerita anak berbasis budaya lokal. Setelah itu, peneliti mencari informasi mengenai buku cerita anak yang ada di Sekolah Dasar.

Untuk memperoleh data yang mendalam, peneliti melakukan observasi dengan berkunjung ke Benteng Rotterdam dan perpustakaan Kota Makassar serta melakukan wawancara dengan ahli budaya yaitu dengan masyarakat, guru SD dan pustakawan.

Tahap observasi dilakukan dengan melakukan pengamatan langsung di SD Kartika XX-I Makassar. Untuk mendapatkan data awal, peneliti menggunakan instrumen berupa kuesioner untuk mengetahui budaya literasi di sekolah. Pengolahan data dilakukan dengan cara mentabulasi, menganalisa, dan menafsirkan data dari tiaptiap responden. Hasil analisis data bertujuan untuk menarik kesimpulan dari hasil kuesioner siswa. Dokumentasi digunakan untuk mendokumentasikan setiap kegiatan yang dilakukan untuk mendukung hasil penelitian. Data isian kuesioner direkapitulasi untuk mengetahui jawaban responden dan persentase jawaban responden pada tiap soal. Dalam hal ini, peneliti menggunakan Skala Likers, Sugiyono (2016: 136).

Tabel 2. Persentase frekuensi Jawaban

\begin{tabular}{ccc}
\hline No & Skala Jawaban & Nilai \\
\hline 1 & Sangat setuju & 5 \\
2 & Setuju & 4 \\
3 & Ragu-ragu & 3 \\
4 & Kurang setuju & 2 \\
5 & Tidak setuju & 1 \\
\hline
\end{tabular}


Setelah itu, menentukan nilai rating scale dan jarak interval dari nilai tabel di atas:

Tabel 3. Nilai Rating Scale dan Jarak Interval

\begin{tabular}{cc}
\hline Rumus & Skala \\
\hline $81-100$ & Sangat Baik \\
$61-80$ & Baik \\
$41-60$ & Sedang \\
$21-40$ & Rendah \\
$0-20$ & Sangat Rendah \\
\hline
\end{tabular}

(Sumber: Arikunto, 2010: 207)

Setelah semua data terkumpul, langkah selanjutnya adalah menganalisis datadata tersebut dan ditarik kesimpulan. Teknik analisis data dalam penelitian ini menggunakan teknik analisis data deskriptif persentase, karena yang termasuk dalam statistik deskriptif adalah dengan penyajian data melalui tabel, grafik, perhitungan ratarata, dan persentase (Sugiyono, 2007: 85).

\section{HASIL PENELITIAN DAN PEMBAHASAN}

Penelitian ini dilaksanakan ini dilaksanakan di SD Kartika XX-1 Kota Makassar yang terletak di tengah kota Makassar yang beralamatkan di Jl. Dr. Ratulangi No. 57 Mamajang Luar Kecamatan Mamajang Kota Makassar Provinsi Sulawesi Selatan. Sekolah ini berdiri di atas tanah seluas $2326 \mathrm{~m}^{2}$ yang berada di bawah naungan Yayasan Kartika. Sekolah yang sudah memiliki status akreditasi A ini awalnya menerapkan kurikulum KTSP yang kemudian berubah menjadi kurikulum K-13 pada tahun 2018. Sekolah ini dipimpin oleh Kepala Sekolah bernama Drs. Syahrun, M.Pd, dengan memiliki jumlah guru kelas sebanyak 12 guru kelas dan 7 orang guru bidang studi. Sedangkan jumlah ketenagaan sebanyak 9 orang yang terdiri dari administrasi, penjaga/kebersihan sekolah, pustakawan, Lab. komputer dan keamanan. Sekolah ini memiliki jumlah siswa sebanyak 286 siswa yang terdiri dari 151 siswa laki-laki dan 135 siswa perempuan.

Tabel. 4 Hasil kuesioner budaya literasi siswa

\begin{tabular}{ccccc}
\hline No. & Klasifikasi & Interval skor & Frekuensi & Persentase \\
\hline 1 & Sangat baik & $81-100$ & 16 & $36 \%$ \\
2 & Baik & $61-80$ & 26 & $58 \%$ \\
3 & Cukup & $41-60$ & 3 & $6 \%$ \\
4 & Kurang & $21-40$ & 0 & 0 \\
5 & Sangat kurang & $0-20$ & 0 & 0 \\
& Total & & 45 & 100 \\
\hline
\end{tabular}

Berdasarkan tabel diatas, dapat dilihat bahwa ada $16(36 \%)$ siswa berada dikategori sangat baik, 26 (58\%) siswa berada di kategori baik, $3(6 \%)$ siswa berada di kategori cukup. Berdasarkan kategori kuesioner dapat disimpulkan bahwa budaya literasi siswa di SD Kartika dapat diklasifikasikan baik dalam penerapan literasi. Hal tersebut ditunjukkan dengan adanya 58\% siswa menganggap bahwa penerapan literasi 
di sekolah mereka sudah diterapkan. Selain pembiasaan membaca, pembudayaan literasi juga didukung dengan sarana penunjang kegiatan literasi seperti majalah dinding dan tulisan-tulisan yang menggugah minat siswa untuk membaca. Berdasarkan wawancara dengan salah satu guru wali kelas mengungkapkan bahwa SD Kartika XX-I Makassar mendukung kegiatan literasi dengan turut serta menghidupkan madingmading di sekolah dan juga pojok baca di setiap kelas.

Berdasar hasil wawancara tentang jenis buku cerita berbasis budaya lokal yang ada di lingkungan masyarakat, perpustakaan Kota Makassar dan juga di sekolah bahwa budaya lokal adalah sebuah warisan dengan nilai-nilai luhur sejak dahulu kala yang perlu untuk diketahui dan diterapkan oleh masyarakat secara umum termasuk anakanak. Budaya lokal adalah budaya asli atau ciri khas sebuah kelompok dalam berinteraksi yang terkait dengan tempat dan masalah geografis, seperti yang dikatakan budayawan I bahwa:

"Gambaran umum tentang budaya lokal yang ada di Sulawesi Selatan yaitu memiliki keunggulan dan letak geografis dan etnik budaya. Masyarakat Sulawesi Selatan terdiri dari etnik budaya yang memiliki nilai-nilai luhur yang yang diangkat dari nilai tradisional dan budaya lokal yang secara universal dapat dipadukan dengan cara pandang global. Nilai dari budaya lokal tersebut berfungsi sebagai rambu-rambu dalam pelaksanaan aktivitas dalam tatanan masyarakat itu sendiri"

Ada beberapa nilai budaya lokal yang saat ini masih dimiliki oleh masyarakat dalam kehidupan sehari-hari. Sumber budaya lokal tersebut mengenai nilai-nilai agama, kebiasaan dan petuah atau adat istiadat.

"Budaya lokal masih kita dapatkan dalam kehidupan sehari-hari. Di Sulawesi Selatan pada khususnya, budaya lokal masih sangat kental dan masih bisa kita temui dalam kehidupan sehari-hari. Salah satu contoh yang bisa kita lihat adalah budaya siri' dan saling menghormati satu sama lainnya. Ketika yang muda berbicara kepada yang lebih tua misalnya, yang muda tidak menyebut nama melainkan dengan panggilan "daeng".

Narasumber menambahkan bahwa:

"Nilai-nilai yang ada dalam suku bugis Makassar adalah nilai-nilai kejujuran, kesopanan, adat istiadat dan saling menghormati sesama. Pangngalik berarti segan, takut atau merupakan rasa hormat. Sipakatau merupakan sikap yang memanusiakan manusia seutuhnya dalam kondisi apapun. Sipakainge merupakan sifat saling mengingatkan untuk senantiasa melakukan kebaikan. Sipakalabbiri merupakan saling menghargai atau selalu ingin menghargai dan dihargai. "Abbulo sibatang paki antu, mareso tamattappu nanampa nia sannang ni pusakai". Artinya bekerja dengan jujur dan sama sama untuk menghasilkan pekerjaan yang baik sehingga memberikan kesenangan bersama"

Sayangnya, beberapa budaya lokal juga sudah mulai terkikis seiring berjalannya waktu dan berubahnya zaman.

"Pergeseran tersebut terjadi seiring dengan perkembangan zaman khususnya berkembangan teknologi. Jadi kebiasaan budaya yang masih melekat hanyalah kebiasaan yang sering dilakukan sedangkan kebiasaan yang jarang dilakukan itulah yang berangsur-angsur mulai hilang. Misalnya sikap sipammase-mase yang merupakan sikap saling membantu satu sama lain tetapi sudah mengalami perubahan dimana pemuda yang merupakan penerus bangsa lebih memikirkan diri mereka sendiri dan terlena dengan gaya hidup sekarang. Hal tersebut disebabkan berbagai macam alat elektronik seperti HP dan TV." 
Oleh sebab itulah, perlu dilakukan berbagai cara untuk tetap memupuk dan melestarikan budaya lokal. Salah satunya melalui cerita anak berbasis budaya lokal. Dari data yang diperoleh memperlihatkan bahwa sangat kurang ditemukan cerita anak budaya lokal yang ada di sekolah. Kebanyakan dari buku cerita yang ada adalah tentang cerita anak yang berasal dari daerah lain. Hal tersebut diperoleh dari hasil observasi ke sekolah dan wawancara yang dilakukan oleh narasumber II.

"Tidak ada, kebanyakan buku cerita anak yang terdapat di sekolah adalah buku cerita yang berasal dari daerah lain, di luar daerah Sulawesi Selatan. Begitu pula dengan buku pelajaran”

Peneliti juga menelusuri dan menemukan fakta bahwa ketersediaan buku cerita di perpustakaan Kota Makassar sangat minim. Hal tersebut dibuktikan dengan mendatangi perpustakaan dan melakukan wawancara dengan pustakawan. Beliau menjelaskan bahwa pasokan buku yang masuk kurang lebih 2 buku dalam setahun.

Berdasarkan data yang didapat bahwa cerita anak berbasis budaya lokal cukup sulit didapatkan baik di dalam sekolah mau di perpustakan umum Kota Makassar. Di SD Kartika XX-I Makassar khususnya, terdapat beberapa judul buku cerita anak tapi merupakan buku cerita anak nusantara dan tidak mengandung nilai budaya Lokal Bugis Makassar. Dari data tersebut kemudian dilakukan identifikasi cerita anak berbasis budaya Bugis Makassar. Dari hasil identifikasi, terdapat 12 judul cerita yang berbasis budaya lokal yang bisa diterapkan untuk meliterasi siswa SD Kartika XX-I Makassar. Beberapa judul cerita yang diidentifikasi adalah kisah putri tandampalik, daeng sinoraja, nenek pakande, ambo upe dan burung beo, cerita la upe dan raja ikan, I laurang manusia udang, kisah sawerigading, Lamaddukelleng, pung darek-darek na pung kura-kura, sepak bola binatang, la tongko-tongko dan kisah penakluk rajawali dari Sulawesi selatan. Keduabelas judul cerita tersebut berasal dari daerah Sulawesi Selatan yang kemudian disatukan dan diliterasikan kepada siswa.

Kisah putri tandampalik mengandung nilai moral bugis makassar yaitu pacce' yang artinya perasaan pedih dan perih yang dirasakan meresap dalam kalbu seseorang, karena melihat penderitaan orang lain. Pacce' merupakan panggilan hati nurani untuk menyatakan sikap kesetiakawanan sosial yang mendorong adanya perbuatan tolong menolong. Kisah Daeng Sinoraja mengandung nilai moral pentingnya sikap menghargai dan tolong menolong. Sikap tersebut tergambar dalam budaya Bugis Makassar yaitu abbulo sibatang; mengandung makna rasa solidaritas yang tinggi untuk saling membantu, dalam menghadapi setiap tantangan dan kesulitan. Kisah nenek pakande mengandung nilai moral yaitu tudang sipulang yang artinya duduk bersama membicarakan dan memecahkan sebuah masalah untuk mencapai kesepakatan dan abbulo sibatang; mengandung makna rasa solidaritas yang tinggi untuk saling membantu, dalam menghadapi setiap tantangan dan kesulitan.

Kisah ambo upe dan burung beo mengandung nilai moral yaitu pacce yang artinya ada rasa kasihan dan tidak tega melihat penderitaan orang lain sehingga timbul rasa ingin membantu sekalipun itu dengan binatang. Begitu pula cerita La Upe dan raja ikan, I Laurang manusia udang, kisah Sawerigading, Lamaddukelleng, pung darekdarek na pung kura-kura, sepak bola binatang, la tongko-tongko dan kisah penakluk rajawali dari Sulawesi selatan memiliki pesan moral budaya lokal yang perlu untuk diketahui oleh siswa.

Sebenarnya, banyak tujuan yang ingin dicapai dalam pelaksanaan pembudayaan literasi sekolah yang dikemas dalam program kegiatan literasi, diantaranya bermula dari keresahan bangsa terhadap minat baca yang rendah di mata dunia, untuk itu gerakan 
pembudayaan membaca diharapkan dapat meningkatkan wawasan siswa, serta sebagai salah satu cara yang dapat dilakukan dalam pembentukan karakter siswa berdasarkan budaya lokal.

Berdasarkan permendikbud No. 23 tahun 2015 bahwa Pembiasaan literasi untuk menumbuhkan minat baca melalui kegiatan 15 menit membaca. Olehnya itu, penerapan budaya literasi di SD Kartika XX-I Makassar dengan menggunakan cerita anak berbasis budaya Makassar dilakukan dengan membagikan buku cerita kepada siswa. Setelah di beri waktu sekitar 15-20 menit untuk membaca cerita, siswa tersebut di beri kesempatan untuk menyebutkan judul cerita dan menceritakan kisah yang telah di bacanya serta mengidentifikasi nilai moral yang terdapat dalam cerita tersebut. Hal tersebut didukung oleh penelitian sebelumnya yang dilakukan oleh Chasanah dkk (2008: 45) bahwa Penelitian pragmatik sastra mengkaji cerita rakyat yang mengandung pesan moral cukup banyak dan dapat dikembangkan untuk anak usia dini. Selain itu, Piaget, Kohlberg dalam Musfiroh (2008: 66) juga menunjukkan bahwa cerita berperan dalam pembentukan moral. Piaget pada tahun 1965 mengukur perkembangan moral anak dengan menggunakan cerita. Cara yang dilakukan adalah dengan menyimak pertimbangan moral anak setelah mendengar cerita. Kohlberg juga demikian, yaitu mengukur moral dengan cara yang sama yaitu menggunakan cerita.

Setelah itu, dilakukan penguatan nilai-nilai moral cerita anak dan penerapan budaya lokal yang sesuai dengan nilai kebangsaan. Penerapan literasi di sekolah sangat menunjang proses pembelajaran sejalan dengan pendapat Syarif (2016, h. 14) menyatakan bahwa menanamkan nilai-nilai budaya lokal dalam proses pembelajaran sangat penting untuk dilakukan. Beberapa penerapan budaya lokal yang diterapkan seperti budaya tabe' yang mana ketika seseorang lewat didepan orang yang lebih tua haruslah membungkuk dengan rasa hormat, nilai Pacce' merupakan panggilan hati nurani untuk menyatakan sikap kesetiakawanan sosial yang mendorong adanya perbuatan tolong menolong dan abbulo sibatang; mengandung makna rasa solidaritas yang tinggi untuk saling membantu, dalam menghadapi setiap tantangan dan kesulitan. Hal tersebut sesuai dengan nilai kebangsaan Indonesia yaitu nilai-nilai saling menghormati dan menghargai serta bermusyawarah untuk memutuskan hal-hal yang dianggap penting untuk kebaikan bersama.

Perbedaan penelitian ini dengan penelitian sebelumnya oleh Munandar, dkk (2018: h. 152-162) peneliti melakukan penelitian di daerah Tasikmalaya yang hanya memaparkan penggunaan buku cerita anak berbasis kearifan lokal mendong Tasikmalaya di sekolah dasar sedangkan penelitian ini memberikan data tentang dua belas cerita anak serta membahas nilai moral berbasis budaya lokal khususnya Bugis Makassar di tiap ceritanya yang kemudian diliterasikan ke siswa. Sangat diharapkan untuk penelitian selanjutnya, agar mengidentifikasi cerita anak berbasis budaya lokal lebih banyak lagi atau bahkan melakukan pengembangan cerita anak yang mengandung nilai moral budaya lokal khususnya Bugis Makassar.

\section{SIMPULAN}

Berdasar hasil analisis dan pembahasan dalam penelitian ini, maka disimpulkan bahwa (1) Judul cerita anak yang teridentifikasi sebanyak 12 judul cerita anak diantaraya adalah kisah putri tandampalik, daeng sinoraja, nenek pakande, ambo upe dan burung beo, cerita la upe dan raja ikan, I laurang manusia udang, kisah sawerigading, Lamaddukelleng, pung darek-darek na pung kura-kura, sepak bola 
binatang, la tongko-tongko dan kisah penakluk rajawali dari Sulawesi selatan. Ke dua belas judul cerita tersebut berasal dari daerah Sulawesi Selatan yang kemudian disatukan dan diliterasikan kepada siswa. (2) Penerapan budaya literasi yang dilakukan di SD Kartika XX-1 Makassar dengan a) membagikan buku cerita kepada siswa b) membaca sekitar 15-20 menit, c) siswa mengidentifikasi nilai moral yang terdapat dalam cerita tersebut, d) melakukan penguatan nilai-nilai moral cerita anak dan penerapan budaya lokal yang sesuai dengan nilai kebangsaan. (3) Beberapa penerapan budaya lokal yang diterapkan seperti budaya tabe' yaitu haruslah membungkuk dengan rasa hormat di depan orang yang lebih tua, nilai Pacce' merupakan panggilan hati nurani untuk menyatakan sikap kesetiakawanan sosial yang mendorong adanya perbuatan tolong menolong dan abbulo sibatang; mengandung makna rasa solidaritas yang tinggi untuk saling membantu. Hal tersebut sesuai dengan nilai kebangsaan Indonesia yaitu nilai-nilai saling menghormati dan menghargai serta bermusyawarah untuk memutuskan hal-hal yang dianggap penting untuk kebaikan bersama.

\section{DAFTAR PUSTAKA}

Arikunto, S. (2010). Prosedur Penelitian Suatu Pendekatan Praktik. Jakarta: PT Rineka Cipta

Buchori, S., \& Fakhri, N. (2018). Nilai-Nilai Kedamaian Dalam Perspektif Suku Bugis Dan Makassar. Journal of Multicultural Studies in Guidance and Counseling, 2(1), 4 .

Chasanah, I, dkk. 2008. Pembentukan Karakter Anak Menurut Teks Cerita Rakyat Ranggana Putra Demang Balaraja: Kajian Prakmatik Sastra. Jurnal Penelitian Dinas Sosial, (7)1.

Fajarini, U. (2014). Peranan Kearifan Lokal Dalam Pendidikan Karakter. Jurnal Sosio Didaktika, 1(2), 123.

Fatimah, N. (2017). Pengembangan Buku Cerita Rakyat Bima Berbasis Kearifan Lokal. Jurnal NOSI, 5(3), 268.

Kementerian Pendidikan dan Kebudayaan. (2015). Manual Pendukung Pelaksanaan Gerakan Literasi Sekolah. Direktorat Jenderal Pendidikan Dasar Dan Menengah direktorat Pembinaan Sekolah Menengah Pertama. Jakarta: Kemendikbud.

Munandar, A., Mulyadiprana, A., Apriliya, S. (2018). Penggunaan Buku Cerita Anak Berbasis Kearifan Lokal Mendong Tasikmalaya di Sekolah Dasar. Pedadidaktika: jurnal ilmiah Pendidikan guru sekolah dasar 5(2), 152-162

Musfiroh, T. (2008). Memilih, Menyusun, dan Menyajikan Cerita untuk Anak Usia Dini. Yogyakarta: Tiara Wacana

Rosdiana, Y, dkk. (2013). Bahasa dan Sastra Indonesia di SD. Tangerang Selatan: Universitas Pamulang

Sarumpaet, A, dkk. (1992). Permainan Besar. Jakarta: Dirjen Dikti Proyek Pembinaan Tenaga Kependudukan.

Sugiyono. (2009). Metode Penelitian Kualitatif, Kuantitatif dan R\&D. Bandung: Alfabeta.

.. (2011). Metode Penelitian Kuantitatif dan Kualitatif dan $R \& D$. Bandung: CV Alfabeta. .. (2016). Metode Penelitian Pendidikan. Bandung: Alfabeta. 
Sulham, H. (2006). Pengembangan Karakter Pada Anak Didik: Manajemen Pembelajaran Guru Menuju Sekolah Yang Efektif. Surabaya: Intelektual. Hamidi.

Suyadi. (2010). Psikologi Belajar Anak Usia Dini. Yogyakarta: Pedagogia.

Syarif, E., Sumarmi., Fatchan, A., Astina, K. (2016). Integrasi Nilai Budaya Etnis Bugis Makassar Dalam Proses Pembelajaran Sebagai Salah Satu Strategi Menghadapi Era Masyarakat Ekonomi Asean (MEA). Jurnal Teori dan Praksis Pembelajaran IPS, 1(1), 2503-5347.

Teguh, M. (2017). Aktualisasi Kurikulum 2013 di Sekolah Dasar melalui Gerakan Literasi di Sekolah untuk Menciptakan Generasi Unggul dan Berbudi Pekerti. Prosiding Seminar Nasional

Wibowo, A, dkk. (2015). Pendidikan Karakter Berbasis Kearifan Lokal Di Sekolah. Yogyakarta: Pustaka pelajar.

Yuniati, Y., Yuningsih, A., Ratmanto, T. (2017). Gerakan Literasi Sekolah dalam Menumbuhkan Minat Baca. Prosiding SNaPP2017 Sosial, Ekonomi, dan Humaniora, 7(2), 368. 